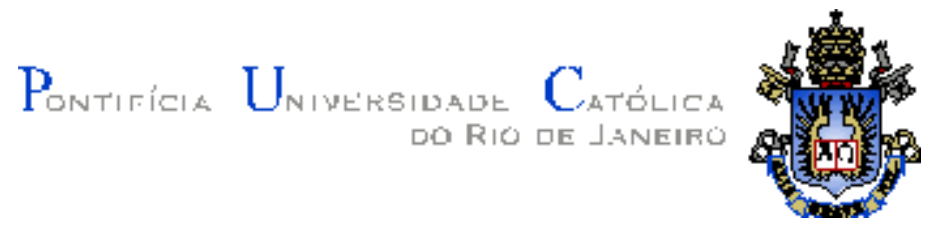

Ellen C. Cruz de Lima

\title{
A FAZENDA JESUÍTICA DE SANTA CRUZ E SUAS MODIFICAÇÕES PARA ATENDER AS EXIGÊNCIAS REAIS E IMPERIAIS.
}

Dissertação de pós graduação Lato Sensu

Dissertação apresentada ao Programa de Pós-graduação em História da Arte e da Arquitetura no Brasil da PUC-Rio como requisito parcial para a conclusão do curso de especialização em História da Arte e da Arquitetura no Brasil. 
Rio de janeiro, dezembro de 2014

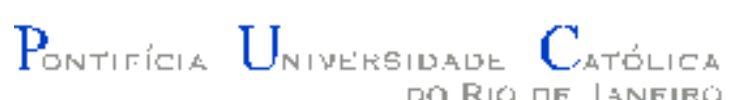
DO RIO DE JANEIRO

Ellen C. Cruz de Lima

\section{A Fazenda Jesuítica de Santa Cruz e Suas Modificações Para Atender as Exigências Reais e imperiais}

Dissertação apresentada como requisito parcial para a conclusão do curso de especialização pelo Programa de Pós-graduação em História da Arte e da Arquitetura no Brasil da PUC-Rio. Aprovada pela Comissão Examinadora abaixo assinada.

Prof.

Orientador

Departamento de História - PUC-Rio 
Rio de Janeiro, dezembro de 2014

Todos os direitos reservados. É proibida a reprodução total ou parcial do trabalho sem autorização da universidade, da autora e do orientador.

\section{Ellen C. Cruz de Lima}

Graduou-se em Artes Visuais pelo Centro Universitário Metodista Bennet em 2008. Atualmente trabalha na rede Municipal e Estadual de ensino do Rio de Janeiro

Ficha catalográfica

Lima, Ellen C. Cruz

A Fazenda Jesuítica de Santa Cruz e Suas Modificações Para Atender as Exigências Reais e Imperiais / Ellen Cristine Cruz de Lima; orientador: Cesar Augusto Tovar Silva - Rio de Janeiro: PUC, Departamento de História, 2014

$57 \mathrm{f}$.

Dissertação (pós graduação lato sensu) - Pontifícia Universidade Católica, Departamento de História

1. Fazenda de Santa Cruz 2.Jesuítas

I.Título

Inclui referências Bibliográficas 


\section{Agradecimentos}

Ao meu orientador, Professor Cesar Augusto Tovar Silva, que foi uma das grandes inspirações para a realização dessa pesquisa, enquanto ministrava suas aulas de História da Arte e Arquitetura I. Agradeço toda atenção, e valiosa solicitude que dirigiu à minha pesquisa. E por todos os auxílios concedidos para a realização deste trabalho.

À todos os professores do curso, que foram fonte de inspiração e conhecimento durante todo o período letivo.

À minha amada irmã, com que a vida me ensinou, e ainda ensina, que posso contar em todas as horas.

À minha mãe, por quem tenho infinda admiração e por quem de fato eu dedico tudo que faço nessa vida.

Aos professores que participaram da Comissão examinadora.

À minha amiga de curso Mariana Massoti, por toda a parceria até o segundo semestre do curso, com quem dividi bons momentos.

Ao comandante do Batalhão escola de engenharia que autorizou minha visita ao prédio e me ofereceu como guia o solícito e gentil o cabo Melo. 


\section{Resumo}

Lima, Ellen C, Cruz; A Fazenda Jesuítica de Santa Cruz e Suas Modificações Para Atender as Exigências Reais e imperiais. Rio de Janeiro, 2014. Dissertação de pós graduação (Lato sensu) - Departamento de história, Pontifícia Universidade Católica do Rio de Janeiro.

Os jesuítas edificaram estruturas complexas, que fizeram de Santa Cruz uma terra produtiva, autônoma e sustentável. Após a expulsão dos jesuítas do Brasil, a sede fazenda jesuítica de Santa Cruz, ficou à serviço das utilizações Reais e em seguida Imperiais. O presente trabalho faz um estudo das diversas descaracterizações que sofreu a sede da antiga fazenda jesuítica para atender as utilizações de seus ocupantes. E como essa transformação se deu ao longo das administrações.

\section{Palavras-chave}

Jesuítas - Fazenda de Santa Cruz - Residência Real - Residência Imperial - arquitetura - Rio de Janeiro 


\section{Sumário}

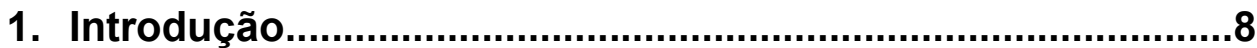

2. Companhia de Jesus: Competência e engenho na formação da identidade da fazenda de Santa Cruz...............................10

2.1. A Companhia de Jesus no Rio de Janeiro..............................10

2.2. Os jesuítas e a fazenda de Santa Cruz.................................13

2.3 Remontando as origens da
fazenda......................................19

3. A organização arquitetônica da fazenda............................23

3.1 Arte e arquitetura jesuítica no Rio de Janeiro...........................23

3.2 Características arquitetônicas da sede da fazenda dos jesuítas..

3.3 Características arquitetônicas do prédio sede da fazenda dos jesuítas.

\section{A fazenda de Santa Cruz e as modificações Reais e Imperiais.}

4.1. O sequestro da fazenda e a expulsão dos Jesuítas. 39

4.2. Santa Cruz, o Palácio Real..................................................42

4.3. Santa Cruz, o Palácio Imperial.................................................47

4.4. Santa Cruz através dos tempos...........................................50

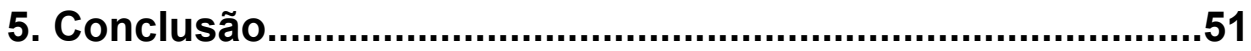

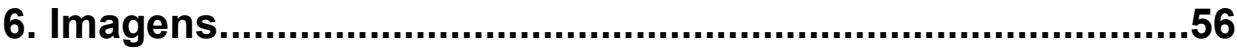

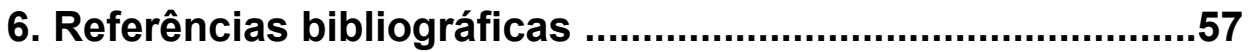

